\title{
THE LIVER LIPID FATTY ACID COMPOSITION OF TWO CARTILAGINOUS FISH, THE THORNBACK RAY (Raja clavata) AND THE COMMON SMOOTH-HOUND (Mustelus mustelus)
}

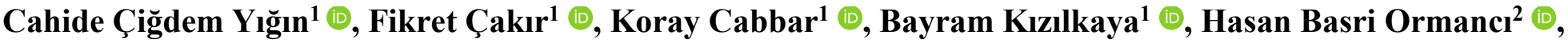 \\ Alkan Öztekin'1 (D), Yeliz Özüdoğrü ${ }^{3}$ (D)
}

\section{Cite this article as:}

Yığın, C.Ç., Çakır, F., Cabbar, K., Kızılkaya, B., Ormancı, H.B., Öztekin, A., Özüdoğru, Y. (2019). The liver lipid fatty acid composition of two cartilaginous fish, the thornback ray (Raja clavata) and the common smooth-hound (Mustelus mustelus). Aquatic Research, 2 (3), $143-153$.

https://doi.org/10.3153/AR19012

${ }^{1}$ Çanakkale Onsekiz Mart University, Faculty of Marine Science and

Technology, 17100, Çanakkale, Turkey

${ }^{2}$ Çanakkale Onsekiz Mart University, Çanakkale School of Applied Sciences, Department of Fisheries Technology, 17100, Çanakkale, Turkey

${ }^{3}$ Çanakkale Onsekiz Mart University, Faculty of Education, Chemistry Education, 17100, Çanakkale, Turkey

ORCID IDs of the author(s): C.Ç.Y. 0000-0002-8808-2252 F.Ç. 0000-0001-5261-2365 K.C. 0000-0001-5254-1384 B.K. 0000-0001-2345-6789 H.B.O. 0000-0003-3136-9196 A.Ö. 0000-0003-3914-9788

Y.Ö. 0000-0003-0471-6404

Submitted: 16.05 .2019

Revision requested: 14.06 .2019

Last revision received: 28.06 .2019

Accepted: 28.06.2019

Published online: 02.07.2019

Correspondence:

Cahide Çiğdem YIĞIN

E-mail: cyigin@hotmail.com

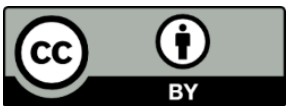

CCopyright 2019 by ScientificWebJournals Available online at

http://aquatres.scientificwebjournals.com

\begin{abstract}
We have evaluated the fatty acid composition of the livers from two cartilaginous fish species Raja clavata (thornback ray) and Mustelus mustelus (common smooth-hound) caught off the Northern Aegean Sea. While there was generally little variation between species, Mustelus mustelus indicated low saturated (SFA) in summer (29.61\%), in spring $(32.57 \%)$, in autumn $(30.07 \%)$ and in winter $(31.81 \%)$ and high polyunsaturated fatty acid (PUFA) in summer $(40.35 \%)$, in spring $(36.50 \%)$, in autumn $(30.21 \%)$ and in winter $(27.26 \%)$ levels. The dominant fatty acids were palmitic acid (C16:0), oleic acid (C18:1 (n-9)), eicosapentaenoic acid (EPA; C20:5 (n-3)), and docosahexaenoic acid (DHA; C22:6 (n-3)) in both cartilaginous fish species in all seasons. The ratio of DHA/EPA with respect to the total of fatty acids in livers oils was ranged from $2.66 \%$ to $4.44 \%$ for Mustelus mustelus and $2.89 \%$ to $4.46 \%$ for Raja clavata. The n:3/n:6 ratio of thornback ray was higher compared to smooth-hound shark in all seasons. The liver oil of $R$. clavata and $M$. mustelus represent a valuable source of omega-3 PUFA that can be used for human and animal nutrition.
\end{abstract}

Keywords: Cartilaginous fish, Fatty acids, Liver, Raja clavata, Mustelus mustelus 


\section{Introduction}

The fish oils, constitute an important source of omega-3 polyunsaturated fatty acids (PUFA), mainly the eicosapentaenoic acid (EPA) and the docosahexaenoic acid (DHA). The omega-3 PUFA provides several benefits to the human health; they have supporting effect on brain and retina development, especially premature children (Navarro-García et al., 2004b; Hoffman and Uauy, 1992). Studies have shown that consumption of fish and fish oil rich in long chain polyunsaturated fatty acids not only reduces the risk of cardiovascular and coronary heart failure (Bigger, 2001; Lee and Lip, 2003), but also cancers, immune system regulators (Side et al., 1998) and supports the development of the brain (Haag, 2003). When the fish is thought to be healthier, both lipid content and PUFA composition should be considered (Aidos, 2002; Nuñez, 2007). However, liver oils from elasmobranchs have the effect of strengthening the immune system in humans, but it can also be used for the prevention of colds, infections, allergies, sinusitis, asthma, low blood pressure, blood sugar reduction and pain relief (Solomon et al., 1997). The liver oil contains high levels of vitamin A and vitamin D, which is very important in preventing diseases such as blindness and rashchitis (Hall, 1992). Cartilaginious fishes are traditionally caught around the world. However, only a few parts are eaten, the caudal fins, and most of the rest is considered as waste (body, viscera, skin) (Le Néchet et al., 2007). Few authors have studied the lipid composition of those byproducts, notably liver and gonads, but they contain a high proportion of lipids (Navarro-García et al., 2004a; NavarroGarcía et al., 2004b; Ould El Kebir, 2003; Pal et al., 1998; Tufan et al., 2013). Also, the studies on lipid and fatty acids in liver oils of cartilaginous fishes in the world have been mostly investigated in deep species (Bordier et al., 1996; Bakes and Nichols, 1995; Deprez et al., 1990).

Information has been reported for thornback ray and smoothhound, liver oils. In the present investigation, the lipids and fatty acids of the liver of the commercial ray and shark species were studied for the first time in the Northern Aegean Sea. In Turkish fishery data, landings of elasmobranchs appear under generic names as "sharks" and "rays" and do not reflect the diversity of Elasmobranchs in Turkish waters at species level. Elasmobranch (sharks and rays) landings reduced from 4040 tonnes in 2000 to 104 tonnes in 2018 that corresponds to a $97.4 \%$ decrease (TUIK, 2018). In Turkey, shark and ray meat consumption is rather limited and elasmobranch catch is mainly processed for export. Meat of $S$. acanthias and M. mustelus are smoked or salted or marketed fresh as whole carcasses for export. Similarly, the wings of rays and skates are processed and marketed skinned and frozen (Kabasakal, 1998). Raja clavata, which is a member of the Rajidae family, is found in the coastal and neritic areas of the Mediterranean; It is a demersal species (Fischer, 1973; Tortonese, 1975). Its distribution areas; Iceland, Norway, North Sea, Mediterranean and Black Sea in the East Atlantic (Compagno et al., 1989). It is distributed in the Marmara Sea, the Aegean Sea, the Mediterranean Sea and the Black Sea in Turkish waters (Mater et al., 2005). Although the coasts prefer sandy-muddy areas with especially soft grounds, It can also be found in various substrates. It ranges from shallow water to a depth of $600 \mathrm{~m}$ (Stehmann, 1990; Mytilineou et al., 2005; Mater et al., 2005). Raja clavata individuals are among the species with high economic importance. Especially in Europe and Far East countries, these fish can be marketed as whole or as a whole along the vertebral system, including the tail and the head, which can be marketed as skinned or skinless with their fins. As canned, it is preferred in hot and cold fuels. It can be prepared by special methods from head and bones in "Meikotsu", a special dish of Chinese and Japanese. Up to $60 \%$ of the liver can be obtained in fat and high in vitamin A, as well as in pipes of some species, vessels in combs, shells, etc. such as ornamental items . In some countries, only internal organs are used in fish flour and fertilizer industry (Akşıray, 1987). Other important cartilaginous fish, Mustelus mustelus, is a benthic species. It is distributed on the sandymuddy grounds of coastal waters, between 5-150 m. depths (Branstetter, 1984). Its distribution areas; ranges from Azore, Madeira, Angola to South Africa, including the East Atlantic, England to the Mediterranean, Morocco and Canary islands, and the Indian Ocean and is distributed in the Marmara Sea, the Aegean Sea and the Mediterranean Sea in Turkish waters (Mater et al., 2005). It is tasty meats with high economic value are prepared by various methods such as fresh, frozen, salted and brine. Also soups and varieties made of fins are preferred in the world. Because of the fat and vitamins found in the liver, it is used in the pharmaceutical industry (Akşıray, 1987).

Sharks and rays liver oil are important raw material which they are rich in EPA and DHA polyunsatured fatty acids (Navarro-García et al., 2004b; Navarro-García et al., 2010). The former authors showed that livers in ray species indicated around $5-11 \%$ of the total fish weight, with an oil content of approximately $50 \%$ of its weight. EPA and DHA represented $16-18 \%$ of the fatty acids present in the oil (Navarro-García et al., 2010). Unfortunately, available literature on liver oil studies from ray and shark species are limited in Turkish Seas (Tufan et al., 2013; Özy1lmaz and Öksüz, 2015; Cabbar and Yığın, 2015; Özyılmaz, 2016). The aims of the present study 
explore the composition of liver oils derived from the thornback rays and smooth-hound.

\section{Material and Methods}

The thornback rays and smooth-hound were obtained seasonal from commercial trawl vessels in the Northern Aegean Sea, off the Babakale and Yeniköy, Turkey. While the mean length and weight of thornback rays were $65.69 \mathrm{~cm}$ and $1868.15 \mathrm{~g}$, the mean length and weight of smooth-hound were $97.95 \mathrm{~cm}$ and $3297.85 \mathrm{~g}$, respectively. The livers of the fish were removed, weighted and stored at $-20^{\circ} \mathrm{C}$ for further analysis. The hepatosomatic index was calculated as the the ratio of liver weight to total body weight. Lipid extraction was carried out according to Bligh and Dyer (1959) method. Homogenized tissue sample is mixed with 1 volume of chloroform and 2 volumes of methanol. After thoroughly vortexing, 1 volume of chloroform is added to the homogenate followed by another mixing step. Afterwards, 1 volume of distilled water is added and subsequently the suspension is stirred for an additional incubation period. The resulting suspension consists of non-extractable residues in a chloroform $/ \mathrm{methanol} /$ water mixture with volumetric ratios $2: 2: 1.8$ $(\mathrm{v} / \mathrm{v} / \mathrm{v})$. This suspension is subsequently filtered through a medium flow filter paper. After a short incubation period, the filtrate is completely phase separated and the upper aqueous layer can be removed. Approximately $10 \mathrm{~g}$ of minced liver samples were used for oil extraction. Chloroform was evaporated using a vacuum rotary evaporator at $40^{\circ} \mathrm{C}$. The remaining fish liver oil were dried at $60^{\circ} \mathrm{C}$ for $30 \mathrm{~min}$. Fatty acid methyl ester (FAME) preparation, chromatographic conditions and fatty acid determination were performed as described (IUPAC, 1979; Özyılmaz and Öksüz, 2015).

Shimadzu GC (Gas Chromatography) was used to determine fatty acids. The system consists of a FID detector (Flame Ionization Detector), a gas chromatograph (Shimadzu, GC 2014, Japan) and an autoinjector (AOC-20i, Shimadzu, Japan). The gas chromatography is controlled by GC solution software (Version 2.41.00 su_1). It was used FAME-WAX (polyethylene glycol, 30 m*0.25 mm I.D*0.2 $\mu \mathrm{m}$, GC Columns
Restek) as chromotographic column. The chromatography operating conditions were identied as follows; 5 minutes at $70^{\circ} \mathrm{C}$, reach $5^{\circ} \mathrm{C} / \mathrm{min}$ increase up to $250^{\circ} \mathrm{C}$, waiting time of 20 minutes at $250^{\circ} \mathrm{C}$. Helium was used as the carrier gas with a flow and split rates of $1.0 \mathrm{ml} / \mathrm{min}$ and $1: 10$, respectively. All analyses were conducted in triplicate. Supelco $37 \mathrm{Com}-$ ponent FAMEs Mix was used for determination of peaks as standard of fatty acids.

The results were statistically evaluated using SPSS 19.0 package program. Significance of difference $(\mathrm{P}<0.05)$ between seasons was determined by one-way ANOVA. Differences between means were determined by Tukey's test.

\section{Results and Discussion}

The descriptive data on the common smoothhound and thornback ray (Table 1) reveal that their average lengths are 97.95 $\pm 10.58 \mathrm{~cm}$ and $67.1 \pm 8.47 \mathrm{~cm}$ and average weights 3297.85 $\pm 1127.11 \mathrm{~g}$ and $1868.15 \pm 766.41 \mathrm{~g}$, respectively. Golani et al. (2006) report that common smooth-hound species having been detected at 50-100 m weight up to $120 \mathrm{~kg}$. Ismen et al. (2009) report that the lengths of male M. mustelus species in the Northern Aegean Sea range between $46.8 \mathrm{~cm}$ and 148.3 $\mathrm{cm}$, while females may measure $49 \mathrm{~cm}$ to $152.2 \mathrm{~cm}$. They also express that the male and female members may weight 390$10270 \mathrm{~g}$ and 382-14431 g, respectively. Özyılmaz and Öksüz (2015) indicate the length of the common smoothhound they captured in the Northwestern Mediterranean Sea as 107.67 $\mathrm{cm}$. Yigin and Ismen (2009) note that the minimum and maximum lengths of the thornback rays they caught in the Northern Aegean Sea are 10-88 cm (disc width: 6-60 cm) for the females and 11-76 cm (disc width: 7-50 cm) for the males. As reported by Yigin and Ismen (2009), their total weights range from $5 \mathrm{~g}$ and $4622 \mathrm{~g}$. Özyılmaz (2016) the total lengths and weights provides that the female $R$. clavata individuals from the Mediterranean Sea measure $53.9 \mathrm{~cm}$ (disc width: $37.1 \mathrm{~cm}$ ) and weight $980.0 \mathrm{~g}$ and the males $49.5 \mathrm{~cm}$ (disc width: $33.8 \mathrm{~cm}$ ) and $778.5 \mathrm{~g}$, respectively.

Table 1. The total length, disc width, total weight, liver weight and hepatosomatic index of the R. clavata and M. mustelus.

\begin{tabular}{lcccccc}
\hline Measurements & \multicolumn{2}{c}{$\boldsymbol{R}$. clavata $(\mathbf{n}=\mathbf{5 1})$} & \multicolumn{3}{c}{ M. mustelus(n=12) } \\
& Min. & Max. & Mean & Min. & Max. & Mean \\
\hline Total length (cm) & 50.2 & 81.9 & $65.69 \pm 8.47$ & 78 & 113.8 & $97.95 \pm 11.30$ \\
Disc width (cm) & 33.4 & 64.2 & $45.60 \pm 6.88$ & - & - & - \\
Total weight (g) & 705.71 & 3717.27 & $1868.15 \pm 766.41$ & 1442.26 & 5559.85 & $3297.85 \pm 1127.11$ \\
Liver weight (g) & 12.89 & 241.4 & $78.55 \pm 51.99$ & 51.82 & 384.01 & $211.12 \pm 104.23$ \\
HSI (\%) & 1.83 & 7.53 & $3.94 \pm 1.27$ & 3.31 & 9.88 & $6.03 \pm 1.78$ \\
\hline
\end{tabular}

n: Sample size, Min.:Minimum, Max: Maximum 
Hepatosomatic index (HSI) is a measure of the energy reserves in fish and fish generally have smaller livers in poor environmental conditions (Avşar, 2005) Liver is key in reproduction particularly to vitellogenesis in females (Kousteni and Megalogonou, 2011). In cartilaginous fish, females have larger livers than males do to supply the energy they need for the formation of oocytes during vitellogenesis and pregnancy period. Females store more lipid in their livers during the reproductive cycle (Capapé and Reynaud, 2011). In the present study while the HSI values of the $R$. clavata individuals ranged between $1.83 \%$ and $7.53 \%$, those of M. mustelus between $3.31 \%$ and $9.88 \%$. The analyzed values revealed that the liver weights of M. mustelus were higher. Özyllmaz and Öksüz (2015) calculated the HSI values of M. mustelus species captured in Northwestern Mediterranean Sea to be $6.34 \%$. The HSI values were calculated in the other examined ray species as well and found to be $4.24 \%$ in common guitarfish (Rhinobatos rhinobatos), $8.25 \%$ in common stingray (Dasyatis pastinaca), 5.36\% in common eagle ray (Myliobatis aquila), and $5.15 \%$ in lusitanian cownose ray (Rhinoptera marginata).

The fatty acid compositions of $M$. mustelus and $R$. clavata are provided in Table 2 and Table 3 . The unsaturated fatty acids ( $\Sigma$ MUFA and $\Sigma$ PUFA) in the liver lipids of both cartilaginous fish species were observed to be more than the saturated fatty acids ( $\Sigma$ SFA). The total saturated fatty acids ( $\Sigma$ SFA) in $M$. mustelus were realized to be more than those in R. clavata in summer, spring, autumn, and winter. The percentages concerning the saturated fatty acids in each species in this study showed that the dominant ones were myristic acid (C14:0), palmitic acid (C16:0), and stearic acid (C18:0), respectively. The results of previous studies on the liver fatty acid profiles of cartilaginous fish supports this finding (Ould El Kebir, 2003; Navarro-García et al., 2004b; Navarro-García et al.,
2009; Sellami et al., 2014; Özyılmaz and Öksüz, 2015, Özyılmaz, 2016).

While a statistically significant difference in the myristic acid (C14:0) content of the liver lipids of both species was observed in spring, autumn, and winter $(\mathrm{P}<0.05)$, the levels were found to be similar in summer $(\mathrm{P}>0.05)$. Whereas the difference between both species in palmitic acid (C16:0) content was not statistically significant in summer, spring, and winter ( $\mathrm{P}>0.05)$, a significant difference was detected in autumn $(\mathrm{P}<0.05)$. The difference between M. mustelus and $R$. clavata in terms of stearic acid (C18:0) content was found statistically significant $(\mathrm{P}<0.05)$. Oleic acid $(\mathrm{C} 18: 1 \mathrm{n} 9)$ was discovered to be the most dominant monounsaturated fatty acid in all the seasons. The oleic acid values in M. mustelus were $14.21 \%, 19.28 \%, 24.74 \%$, and $23.67 \%$ in spring, summer, autumn, and winter, respectively. On the other hand, those in $R$. clavata were $17.66 \%, 20.11 \%, 22.65 \%$, and $22.67 \%$, respectively. The analysis of the seasonal differences revealed a statistically significant difference between summer and spring in the oleic acid contents of both species $(\mathrm{P}<0.05)$, while no statistical differences was observed between autumn and winter $(\mathrm{P}>0.05)$. Nichol et al. (1998), Ould El Kebir et al. (2007), Le Néchet et al. (2007), Turan et al. (2007), Navarro-García et al. (2009), Tufan et al. (2013), Sellami et al. (2014), Özyılmaz and Öksüz (2015), and Özy1lmaz (2016) report that the oleic acid (C18:1n9) has the highest value among all the monounsaturated fatty acids in $R$. clavata and other stingrays. Besides, in their study on the liver fatty acids in Dasyatis brevis and Gymnura marmorata, Navarro-García et al. (2004b) found higher palmitoleic acid (C16:1) and eicosenoic acid (C20:1) values than oleic acid. The comparison between M. mustelus and $R$. clavata in terms of oleic acid content indicated a statistically significant difference between the values in summer and autumn $(\mathrm{P}<0.05)$, but none was observed in spring and winter $(\mathrm{P}>0.05)$. 
Table 2. Fatty acid (\%) profiles of the R.clavata livers

\begin{tabular}{|c|c|c|c|c|}
\hline Fatty acids & Summer & Spring & Autumn & Winter \\
\hline $\mathrm{C}_{14: 0}$ & $2.31 \pm 0.12^{\mathrm{ab}}$ & $2.04 \pm 0.05^{\mathrm{c}}$ & $2.21 \pm 0.16^{\mathrm{bc}}$ & $2.47 \pm 0.15^{\mathrm{a}}$ \\
\hline $\mathrm{C}_{15: 0}$ & $0.83 \pm 0.05^{\mathrm{c}}$ & $0.86 \pm 0.21^{\mathrm{c}}$ & $1.14 \pm 0.14^{\mathrm{b}}$ & $1.54 \pm 0.04^{\mathrm{a}}$ \\
\hline $\mathrm{C}_{16: 0}$ & $18.23 \pm 0.32^{\mathrm{c}}$ & $21.80 \pm 0.26^{\mathrm{a}}$ & $19.81 \pm 1.37^{b}$ & $22.59 \pm 0.69^{a}$ \\
\hline $\mathrm{C}_{17: 0}$ & $0.95 \pm 0.03^{\mathrm{c}}$ & $1.08 \pm 0.46^{\mathrm{c}}$ & $3.21 \pm 0.14^{\mathrm{a}}$ & $2.17 \pm 0.01^{\mathrm{b}}$ \\
\hline $\mathrm{C}_{18: 0}$ & $9.23 \pm 0.27^{\mathrm{a}}$ & $9.17 \pm 0.81^{\mathrm{a}}$ & $4.11 \pm 0.05^{\mathrm{b}}$ & $4.10 \pm 0.15^{b}$ \\
\hline $\mathrm{C}_{23: 0}$ & $1.16 \pm 0.03^{\mathrm{a}}$ & $1.09 \pm 0.08^{\mathrm{a}}$ & $0.82 \pm 0.38^{\mathrm{a}}$ & $0.27 \pm 0.02^{\mathrm{c}}$ \\
\hline $\mathrm{C}_{14: 1}$ & $0.08 \pm 0.01^{\mathrm{c}}$ & $0.05 \pm 0.01^{\mathrm{c}}$ & $0.30 \pm 0.03^{b}$ & $0.52 \pm 0.01^{\mathrm{a}}$ \\
\hline $\mathrm{C}_{16: 1}$ & $5.64 \pm 0.14^{\mathrm{c}}$ & $5.64 \pm 0.71^{\mathrm{c}}$ & $6.84 \pm 0.24^{\mathrm{b}}$ & $8.06 \pm 0.05^{\mathrm{a}}$ \\
\hline $\mathrm{C}_{17: 1}$ & $0.67 \pm 0.05^{\mathrm{a}}$ & $0.00 \pm 0.00^{\mathrm{d}}$ & $0.41 \pm 0.03^{c}$ & $0.59 \pm 0.01^{b}$ \\
\hline $\mathrm{C}_{18: 1} \mathrm{n} 9+\mathrm{n} 7$ & $14.21 \pm 0.61^{\mathrm{c}}$ & $19.28 \pm 0.81^{b}$ & $24.74 \pm 0.83^{\mathrm{a}}$ & $23.67 \pm 0.57^{\mathrm{a}}$ \\
\hline $\mathrm{C}_{20: 1} \mathrm{n} 9$ & $3.72 \pm 0.02^{\mathrm{b}}$ & $4.90 \pm 0.31^{\mathrm{a}}$ & $3.76 \pm 0.75^{\mathrm{b}}$ & $3.33 \pm 0.33^{b}$ \\
\hline $\mathrm{C}_{22: 1} \mathrm{n} 9$ & $1.68 \pm 0.25^{\mathrm{c}}$ & $2.63 \pm 0.20^{\mathrm{a}}$ & $2.08 \pm 0.21^{\mathrm{b}}$ & $0.55 \pm 0.15^{\mathrm{d}}$ \\
\hline $\mathrm{C}_{24: 1} \mathrm{n} 9$ & $0.38 \pm 0.07^{\mathrm{b}}$ & $0.49 \pm 0.00^{\mathrm{ab}}$ & $0.61 \pm 0.17^{\mathrm{a}}$ & $0.33 \pm 0.13^{b}$ \\
\hline $\mathrm{C}_{18: 2} \mathrm{n} 6 \mathrm{c}$ & $1.57 \pm 0.05^{\mathrm{b}}$ & $1.53 \pm 0.18^{\mathrm{b}}$ & $3.64 \pm 0.26^{\mathrm{a}}$ & $3.77 \pm 0.40^{\mathrm{a}}$ \\
\hline $\mathrm{C}_{18: 3} \mathrm{n} 6$ & $0.59 \pm 0.03^{\mathrm{ab}}$ & $0.46 \pm 0.08^{b}$ & $0.71 \pm 0.18^{\mathrm{a}}$ & $0.53 \pm 0.02^{\mathrm{ab}}$ \\
\hline $\mathrm{C}_{18: 3} \mathrm{n} 3$ & $1.43 \pm 0.04^{\mathrm{a}}$ & $1.26 \pm 0.07^{\mathrm{ab}}$ & $0.87 \pm 0.25^{\mathrm{c}}$ & $1.09 \pm 0.11^{\mathrm{bc}}$ \\
\hline $\mathrm{C}_{20: 2}$ & $0.72 \pm 0.00^{\mathrm{a}}$ & $0.52 \pm 0.11^{\mathrm{b}}$ & $0.31 \pm 0.02^{\mathrm{c}}$ & $0.50 \pm 0.06^{\mathrm{b}}$ \\
\hline $\mathrm{C}_{20: 3} \mathrm{n} 6$ & $0.06 \pm 0.00^{c}$ & $0.06 \pm 0.01^{\mathrm{c}}$ & $0.93 \pm 0.04^{\mathrm{a}}$ & $0.28 \pm 0.01^{\mathrm{b}}$ \\
\hline $\mathrm{C}_{20: 3} \mathrm{n} 3$ & $3.38 \pm 0.08^{\mathrm{a}}$ & $1.45 \pm 0.59^{\mathrm{b}}$ & $1.51 \pm 0.42^{\mathrm{b}}$ & $1.12 \pm 0.41^{\mathrm{c}}$ \\
\hline $\mathrm{C}_{20: 4} \mathrm{n} 6$ & $0.14 \pm 0.03^{b}$ & $0.20 \pm 0.03^{\mathrm{a}}$ & $0.20 \pm 0.03^{\mathrm{a}}$ & $0.00 \pm 0.00^{\mathrm{c}}$ \\
\hline $\mathrm{C}_{20: 5} \mathrm{n} 3$ & $8.40 \pm 0.05^{\mathrm{a}}$ & $4.63 \pm 0.20^{\mathrm{c}}$ & $5.15 \pm 0.24^{\mathrm{b}}$ & $5.32 \pm 0.21^{\mathrm{b}}$ \\
\hline $\mathrm{C}_{22: 2}$ & $0.36 \pm 0.08^{\mathrm{a}}$ & $0.24 \pm 0.02^{b}$ & $0.37 \pm 0.15^{\mathrm{a}}$ & $0.36 \pm 0.02^{b}$ \\
\hline $\mathrm{C}_{22: 6} \mathrm{n} 3$ & $24.26 \pm 0.37^{\mathrm{a}}$ & $20.62 \pm 1.41^{\mathrm{b}}$ & $16.29 \pm 1.74^{c}$ & $16.83 \pm 0.91^{\mathrm{c}}$ \\
\hline$\Sigma$ SFA & 32.9 & 36.03 & 31.28 & 33.15 \\
\hline$\Sigma$ MUFA & 26.56 & 32.99 & 38.74 & 37.04 \\
\hline$\Sigma$ PUFA & 40.55 & 30.98 & 29.97 & 29.81 \\
\hline$\Sigma U F A$ & 67.10 & 63.97 & 68.72 & 66.85 \\
\hline$\Sigma \omega-3$ & 37.08 & 27.96 & 23.82 & 24.36 \\
\hline$\sum \omega-6$ & 2.38 & 2.25 & 5.48 & 4.59 \\
\hline$\Sigma \omega-9$ & 20.12 & 27.3 & 31.20 & 27.88 \\
\hline$\Sigma \omega-3 / \Sigma \omega-6$ & 15.58 & 12.43 & 4.35 & 5.31 \\
\hline DHA/EPA & 2.89 & 4.46 & 3.16 & 3.17 \\
\hline
\end{tabular}

$\mathrm{a}, \mathrm{b}, \mathrm{c}$ indicated statistical differences between seasons $(\mathrm{P}<0.05)$. Mean values \pm S.D. of determination for triplicate samples. SFA- saturated fatty acids; PUFA- polyunsaturated fatty acids; UFA- unsaturated fatty acids; DHA-docosahexaenoic acid; EPA-eicosapentaenoic acid. 
Table 3. Fatty acid (\%) profiles of the M. mustelus livers

\begin{tabular}{|c|c|c|c|c|}
\hline Fatty acids & Summer & Spring & Autumn & Winter \\
\hline $\mathrm{C}_{14: 0}$ & $2.65 \pm 0.20^{\mathrm{b}}$ & $3.19 \pm 0.07^{\mathrm{a}}$ & $2.75 \pm 0.04^{\mathrm{b}}$ & $3.14 \pm 0.29^{\mathrm{a}}$ \\
\hline $\mathrm{C}_{15: 0}$ & $0.11 \pm 0.02^{\mathrm{d}}$ & $0.84 \pm 0.04^{\mathrm{a}}$ & $0.25 \pm 0.04^{\mathrm{b}}$ & $0.19 \pm 0.03^{c}$ \\
\hline $\mathrm{C}_{16: 0}$ & $18.64 \pm 0.61^{b}$ & $22.12 \pm 1.37^{\mathrm{a}}$ & $22.94 \pm 1.04^{\mathrm{a}}$ & $23.75 \pm 0.98^{\mathrm{a}}$ \\
\hline $\mathrm{C}_{17: 0}$ & $1.17 \pm 0.11^{\mathrm{c}}$ & $1.38 \pm 0.10^{\mathrm{b}}$ & $1.17 \pm 0.02^{\mathrm{c}}$ & $1.71 \pm 0.14^{\mathrm{a}}$ \\
\hline $\mathrm{C}_{18: 0}$ & $6.84 \pm 1.08^{\mathrm{a}}$ & $4.92 \pm 1.17^{b}$ & $2.84 \pm 0.04^{\mathrm{c}}$ & $3.02 \pm 0.33^{c}$ \\
\hline $\mathrm{C}_{20: 0}$ & $0.00 \pm 0.00$ & $0.00 \pm 0.00$ & $0.00 \pm 0.00$ & $0.00 \pm 0.00$ \\
\hline $\mathrm{C}_{21: 0}$ & $0.00 \pm 0.00$ & $0.00 \pm 0.00$ & $0.00 \pm 0.00$ & $0.00 \pm 0.00$ \\
\hline $\mathrm{C}_{22: 0}$ & $0.00 \pm 0.00$ & $0.00 \pm 0.00$ & $0.00 \pm 0.00$ & $0.00 \pm 0.00$ \\
\hline $\mathrm{C}_{23: 0}$ & $0.21 \pm 0.13^{\mathrm{a}}$ & $0.12 \pm 0.03^{\mathrm{ab}}$ & $0.12 \pm 0.03^{\mathrm{ab}}$ & $0.00 \pm 0.00^{\mathrm{b}}$ \\
\hline $\mathrm{C}_{14: 1}$ & $0.78 \pm 0.02^{\mathrm{a}}$ & $0.06 \pm 0.01^{\mathrm{d}}$ & $0.53 \pm 0.04^{b}$ & $0.27 \pm 0.13^{c}$ \\
\hline $\mathrm{C}_{15: 1}$ & $0.00 \pm 0.00^{\mathrm{c}}$ & $0.01 \pm 0.02^{\mathrm{c}}$ & $0.79 \pm 0.06^{\mathrm{b}}$ & $1.19 \pm 0.04^{\mathrm{a}}$ \\
\hline $\mathrm{C}_{16: 1}$ & $4.47 \pm 0.24^{\mathrm{c}}$ & $6.39 \pm 0.43^{b}$ & $8.16 \pm 0.38^{a}$ & $8.85 \pm 1.06^{\mathrm{a}}$ \\
\hline $\mathrm{C}_{17: 1}$ & $0.41 \pm 0.06^{\mathrm{c}}$ & $0.01 \pm 0.02^{\mathrm{d}}$ & $0.86 \pm 0.08^{b}$ & $1.49 \pm 0.06^{\mathrm{a}}$ \\
\hline $\mathrm{C}_{18: 1 \mathrm{n} 9+\mathrm{n} 7}$ & $17.66 \pm 0.28^{c}$ & $20.11 \pm 0.16^{\mathrm{b}}$ & $22.65 \pm 0.49^{\mathrm{a}}$ & $22.67 \pm 1.25^{\mathrm{a}}$ \\
\hline $\mathrm{C}_{20: 1} \mathrm{n} 9$ & $3.64 \pm 0.18^{\mathrm{a}}$ & $2.37 \pm 0.20^{\mathrm{b}}$ & $2.11 \pm 0.08^{\mathrm{b}}$ & $3.63 \pm 0.28^{\mathrm{a}}$ \\
\hline $\mathrm{C}_{22: 1} \mathrm{n} 9$ & $2.96 \pm 0.17^{\mathrm{b}}$ & $1.92 \pm 0.21^{\mathrm{c}}$ & $3.59 \pm 0.39^{\mathrm{a}}$ & $2.83 \pm 0.11^{\mathrm{b}}$ \\
\hline $\mathrm{C}_{24: 1} \mathrm{n} 9$ & $0.12 \pm 0.21^{\mathrm{b}}$ & $0.04 \pm 0.01^{\mathrm{b}}$ & $1.03 \pm 0.02^{\mathrm{a}}$ & $0.00 \pm 0.00^{\mathrm{b}}$ \\
\hline $\mathrm{C}_{18: 2 \mathrm{n} 6 \mathrm{c}}$ & $0.98 \pm 0.04^{b}$ & $1.06 \pm 0.08^{b}$ & $3.83 \pm 0.09^{\mathrm{a}}$ & $3.08 \pm 0.99^{\mathrm{a}}$ \\
\hline $\mathrm{C}_{18: 3 \mathrm{n} 6}$ & $0.38 \pm 0.03^{c}$ & $0.36 \pm 0.01^{\mathrm{c}}$ & $0.54 \pm 0.10^{\mathrm{b}}$ & $0.73 \pm 0.09^{\mathrm{a}}$ \\
\hline $\mathrm{C}_{18: 3 \mathrm{n} 3}$ & $0.77 \pm 0.06^{\mathrm{a}}$ & $1.06 \pm 0.54^{\mathrm{a}}$ & $0.81 \pm 0.02^{\mathrm{a}}$ & $1.00 \pm 0.24^{\mathrm{a}}$ \\
\hline $\mathrm{C}_{20: 2}$ & $0.81 \pm 0.11^{\mathrm{a}}$ & $0.36 \pm 0.05^{b}$ & $0.91 \pm 0.08^{a}$ & $0.36 \pm 0.26^{b}$ \\
\hline $\mathrm{C}_{20: 3} \mathrm{n} 6$ & $0.08 \pm 0.01^{\mathrm{c}}$ & $0.27 \pm 0.01^{\mathrm{c}}$ & $1.80 \pm 0.46^{\mathrm{a}}$ & $0.92 \pm 0.03^{b}$ \\
\hline $\mathrm{C}_{20: 3} \mathrm{n} 3$ & $0.14 \pm 0.01^{b c}$ & $0.10 \pm 0.02^{c}$ & $0.20 \pm 0.06^{\mathrm{b}}$ & $0.38 \pm 0.05^{\mathrm{a}}$ \\
\hline $\mathrm{C}_{20: 4} \mathrm{n} 6$ & $3.61 \pm 0.19^{\mathrm{a}}$ & $2.37 \pm 0.10^{\mathrm{b}}$ & $0.93 \pm 0.25^{\mathrm{c}}$ & $0.70 \pm 0.07^{\mathrm{c}}$ \\
\hline $\mathrm{C}_{20: 5} \mathrm{n} 3$ & $6.13 \pm 0.45^{b}$ & $7.45 \pm 0.55^{\mathrm{a}}$ & $5.37 \pm 0.26^{\mathrm{bc}}$ & $4.81 \pm 0.36^{\mathrm{c}}$ \\
\hline $\mathrm{C}_{22: 2}$ & $0.26 \pm 0.04^{\mathrm{c}}$ & $0.30 \pm 0.04^{\mathrm{c}}$ & $1.57 \pm 0.46^{\mathrm{a}}$ & $0.81 \pm 0.08^{b}$ \\
\hline $\mathrm{C}_{22: 6} \mathrm{n} 3$ & $27.20 \pm 1.03^{\mathrm{a}}$ & $23.18 \pm 0.46^{\mathrm{b}}$ & $14.27 \pm 0.24^{\mathrm{c}}$ & $14.46 \pm 0.25^{\mathrm{c}}$ \\
\hline$\Sigma$ SFA & 29.61 & 32.57 & 30.07 & 31.81 \\
\hline$\Sigma$ MUFA & 30.04 & 30.93 & 39.72 & 40.93 \\
\hline$\Sigma$ PUFA & 40.35 & 36.50 & 30.21 & 27.26 \\
\hline$\Sigma U F A$ & 70.39 & 67.43 & 69.93 & 68.19 \\
\hline$\Sigma \omega-3$ & 34.24 & 31.79 & 20.65 & 20.65 \\
\hline$\Sigma \omega-6$ & 5.05 & 4.06 & 7.1 & 5.43 \\
\hline$\Sigma \omega-9$ & 24.38 & 24.44 & 29.38 & 29.13 \\
\hline$\Sigma \omega-3 / \Sigma \omega-6$ & 6.78 & 7.83 & 2.91 & 3.80 \\
\hline DHA/EPA & 4.44 & 3.11 & 2.66 & 3.00 \\
\hline
\end{tabular}

$\mathrm{a}, \mathrm{b}, \mathrm{c}$ indicated statistical differences between seasons $(\mathrm{P}<0.05)$. Mean values \pm S.D. of determination for triplicate samples. SFA- saturated fatty acids; PUFA- polyunsaturated fatty acids; UFA- unsaturated fatty acids; DHA-docosahexaenoic acid; EPA-eicosapentaenoic acid. 
DHA and EPA of the polyunsaturated fatty acids ( $\mathrm{PPUFA}$ ) were the most dominant fatty acids in a common smoothhound (M. mustelus) and a thornback ray ( $R$. clavata). The EPA values in M. mustelus were revealed to be significantly different in each season $(\mathrm{P}<0.05)$ and the values accounted for $6.13 \%, 7.45 \%, 5.37 \%$, and $4.81 \%$, respectively. The EPA values in $R$. clavata were realized to be similar in autumn $(5.15 \%)$ and winter $(5.32 \%)(\mathrm{P}>0.05)$, while a statistically significant difference was observable in summer $(8.40 \%)$ and spring $(4.63 \%)(\mathrm{P}<0.05)$. The DHA values in $M$. mustelus were discovered to be $27.20 \%, 23.18 \%, 14.27 \%$, and $14.46 \%$ in summer, spring, autumn, and winter, respectively. It was realized that the seasonal difference in summer and spring was statistically significant $(\mathrm{P}<0.05)$, while the difference in the shark's liver lipid was not in autumn and winter $(\mathrm{P}>0.05)$. Similar to the findings related to M. mustelus, the seasonal difference in $R$. clavata individuals were statistically significant in summer and spring $(\mathrm{P}<0.05)$ but not in autumn and winter $(\mathrm{P}>0.05)$. The DHA values of the thornback ray was calculated to be $24.26 \%, 20.62 \%, 16.29 \%$, and $16.83 \%$ in summer, spring, autumn, and winter. The comparison between $R$. clavata and M. mustelus in terms of EPA values indicated a statistically significant difference between these two species in summer and spring $(\mathrm{P}<0.05)$ and none in autumn and winter $(\mathrm{P}>0.05)$. Similarly, the differences in DHA values between both species were observed to be significant in summer, spring, and winter $(\mathrm{P}<0.05)$. But no statistically significant difference in DHA values was observed between $R$. clavata and M. mustelus in autumn $(\mathrm{P}>0.05)$. Özyılmaz and Öksüz (2015) reported the EPA and DHA values in M. mustelus captured at the Iskenderun Gulf in the Northwestern Mediterranean Sea as $2.31 \%$ and $11.81 \%$, respectively. The EPA and DHA values in M. mustelus specimens retrieved in the Northern Aegean Sea for the purpose of this research study were observed to be twice as high as these values. In the study on $R$. clavata individuals captured in the Black Sea and Mediterranean Sea, Özyılmaz (2016) reports the EPA values in the females and males captured in the Black Sea as $7.7 \%$ and $8.9 \%$ and the DHA values as 23.4 and $19.9 \%$, respectively. Özy1lmaz (2016) notes that the EPA values in the females and males of the same species account for $4.5 \%$ and $5.8 \%$ and the DHA values for $26.1 \%$ and $22.4 \%$, respectively. These differences in the EPA and DHA values of the sharks might have resulted from several critical factors such as nutrient composition and water temperature. Planktonic crustaceans are among the primary nutrient resources of sharks; therefore, the EPA and DHA concentrations are influenced by temperature swings in the species habitats. Any increase in water temperature reduces EPA and DHA levels in sharks' livers (Malins et al. 1965; Nuñez 2007). Differences in EPA and DHA levels are also dependent on many other factors such as species, region, age, sex, nutrients, water temperature, feeding environment, and seasons. Moreover, Özyılmaz (2016) revealed statistically significant differences between males and females in terms of the DHA values in $R$. clavata captured in the Black Sea and Mediterranean Sea and noted that these differences resulted from sex and region. Omega-3 and Omega-6 polyunsaturated fatty acids have antagonistic effects on human body. Allen and Harris (2001) remark that the higher amount of the polyunsaturated fatty acid $\varpi-3$ than that of $\varpi-6$ is good for human health. $\varpi-3 / \varpi-6$ ratio is a determinative and crucial factor in the formation of nutritional values of fats. In the present study, $₫-3 / \varpi-6$ ratios in $M$. mustelus were $6.78,7.83,2.91$, and 3.80 in summer, spring, autumn, and winter while those in $R$. clavata were $15.58,12.43,4.35$, and 5.31 respectively. Navarro-García et al. (2014) report this ratio to range between 2.32 and 4.03 in the stingray species $U$. chilensis, $U$. halleri, R. glaucostigma, $R$. steindachneri, and $D$. dipeteura and the highest value in $R$. glaucostigma. The distribution of saturated fatty acids (SFA), monounsaturated fatty acids (MUFA), and polyunsaturated fatty acids (PUFA) in sharks and stingrays in various studies and this research study are presented in Table 4.

\section{Conclusion}

In this study, the $\Sigma$ PUFA values in $R$. clavata and $M$. mustelus were found to range from $32.83 \%$ to $33.58 \%$ and $\Sigma$ MUFA values from $33.83 \%$ to $35.41 \%$. The results suggest that the fatty acid compositions in the livers of cartilaginous fish vary according to species, regions, seasons, sex, age, habitats, nutrient compositions, and water temperature. In conclusion, two cartilaginous fishes has favourable amount of polyunsaturated fatty acid. The major fatty acids identified in $R$. clavata and M. mustelus were 16:0 (palmitic), 18:1 n9 (oleic), and 22:6 n3 (DHA) in all seasons. Indeed, such oil, which could be obtained in relatively high amounts, is an excellent source of omega-3, MUFAs and PUFAs, particularly DHA. Therefore, thornback ray and smoothhound liver oil can be considered to be an alternative to fish oil as a source of EPA and DHA. 
Table 4. Fatty acid composition of liver from various cartilaginous fish species (\%) (M: Male; F: Female)

\begin{tabular}{|c|c|c|c|c|c|}
\hline Species & SFA & MUFA & PUFA & Region & Source \\
\hline Somniosus pacificus & 12.50 & 72.00 & 13.30 & \multirow{6}{*}{ Southern Avustralian waters } & \multirow{6}{*}{ Bakes and Nichols (1995) } \\
\hline Centroscymnus plunketi & 11.50 & 83.60 & 2.60 & & \\
\hline Etmopterus granulosus & 15.00 & 80.00 & 2.50 & & \\
\hline Deania calcea & 26.10 & 64.80 & 7.20 & & \\
\hline Centroscymnus crepidater & 15.70 & 80.20 & 1.41 & & \\
\hline Centrophorus scalpratus & 25.60 & 62.20 & 0.60 & & \\
\hline Carcharhinus falciformis & 35.68 & 19.46 & 37.63 & Gulf of California, & Navarro-García et al. (2000) \\
\hline Galeocerdo cuvier & 30.13 & 33.74 & 14.38 & Caribbean waters & \\
\hline Gymnura spp. & 3.63 & 3.88 & 18.06 & Malaysian waters & Osman et al. (2001) \\
\hline Centroscymnus coelolepis & 18.54 & 53.41 & 28.04 & \multirow{3}{*}{ North Atlantic } & \multirow{3}{*}{ Remme et al. (2005) } \\
\hline Centroscyllium fabricii & 26.81 & 47.82 & 25.38 & & \\
\hline Centrophorus squamosus & 25.59 & 44.70 & 29.47 & & \\
\hline Dasyatis marmorata & $27.47 \mathrm{M}$ & $32.3 \mathrm{M}$ & $39.79 \mathrm{M}$ & \multirow{6}{*}{ East Atlantic Ocean } & \multirow{6}{*}{ Ould El Kebir et al. (2007) } \\
\hline & $39.08 \mathrm{~F}$ & $26.83 \mathrm{~F}$ & $33.1 \mathrm{~F}$ & & \\
\hline Rhinoptera marginata & $51.89 \mathrm{M}$ & $20.74 \mathrm{M}$ & $27.36 \mathrm{M}$ & & \\
\hline & $43.31 \mathrm{~F}$ & $24.11 \mathrm{~F}$ & $31.93 \mathrm{~F}$ & & \\
\hline Rhinobatos cemiculus & $41.55 \mathrm{M}$ & $20.48 \mathrm{M}$ & $37.20 \mathrm{M}$ & & \\
\hline & $42.34 \mathrm{~F}$ & $22.98 \mathrm{~F}$ & $34.17 \mathrm{~F}$ & & \\
\hline Rhinoptera bonasus & 34.40 & 17.90 & 28.60 & \multirow{3}{*}{ Gulf of Mexico } & \multirow{3}{*}{ Navarro-García et al. (2009) } \\
\hline Aetobatus narinari & 38.90 & 19.60 & 20.70 & & \\
\hline Dasyatis americana & 34.50 & 16.10 & 30.30 & & \\
\hline Raja clavata & $27.1-32.1$ & $14.9-19.0$ & $34.3-39.5$ & Black Sea & Tufan et al. (2013) \\
\hline Urotrygon chilensis & 29.30 & 18.15 & 23.61 & \multirow{5}{*}{ Sinaloa, México } & \multirow{5}{*}{ Navarro-García et al. (2014) } \\
\hline Urobatis halleri & 27.29 & 26.47 & 22.62 & & \\
\hline Rhinobatos glaucostigma & 24.72 & 15.67 & 21.73 & & \\
\hline Rhinoptera steindachneri & 9.01 & 7.84 & 10.16 & & \\
\hline Dasyatis dipeteura & 35.62 & 36.25 & 17.28 & & \\
\hline Mustelus mustelus & 34.79 & 43.30 & 20.04 & \multirow{6}{*}{$\begin{array}{l}\text { Northeastern } \\
\text { Mediterranean }\end{array}$} & \multirow{6}{*}{ Özyılmaz and Öksüz (2015) } \\
\hline Rhinobatos rhinobatos & 36.84 & 35.70 & 27.34 & & \\
\hline Dasyatis pastinaca & 34.97 & 41.22 & 22.07 & & \\
\hline Myliobatis aquila & 35.10 & 28.61 & 30.43 & & \\
\hline Rhinoptera marginata & 34.95 & 24.19 & 34.19 & & \\
\hline Carcharhinus altimus & 24.28 & 55.98 & 8.87 & & \\
\hline Raja clavata & $22.50 \mathrm{~F}$ & $30.70 \mathrm{~F}$ & $45.70 \mathrm{~F}$ & Black Sea & \multirow{4}{*}{ Özy1lmaz (2016) } \\
\hline \multirow{3}{*}{ Raja clavata } & $23.00 \mathrm{M}$ & $32.20 \mathrm{M}$ & $43.30 \mathrm{M}$ & \multirow{3}{*}{ Mediterranean } & \\
\hline & $28.40 \mathrm{~F}$ & $23.90 \mathrm{~F}$ & $46.30 \mathrm{~F}$ & & \\
\hline & $29.40 \mathrm{M}$ & $25.87 \mathrm{M}$ & $43.90 \mathrm{M}$ & & \\
\hline Raja clavata & 33.34 & 33.83 & 32.83 & \multirow[t]{2}{*}{ Aegean Sea } & \multirow[t]{2}{*}{ This study } \\
\hline Mustelus mustelus & 31.02 & 35.41 & 33.58 & & \\
\hline
\end{tabular}




\section{Compliance with Ethical Standard}

Conflict of interests: The authors declare that for this article they have no actual, potential or perceived conflict of interests.

Financial disclosure: This research was financially supported by the Canakkale Onsekiz Mart University Scientific Research Projects Coordination Unit, Turkey (FBA-2015-533).

\section{References}

Aidos, I. (2002). Production of High-Quality Fish Oils from Herring By-products. Ph.D. Thesis, Wageningen University, The Netherlands.

Akşıray, F. (1987). Türkiye Deniz Balıkları ve Tayin Anahtar1. 2nd edition. Publication No. 3490. İstanbul: İstanbul University.

Allen, K.G.D., Harris, M.A. (2001). The role of n-3 fatty acids in gestation and parturition. Experimental Biology and Medicine, 226, 498-506.

https://doi.org/10.1177/153537020122600602

PMid:11395920

Avşar, D. (2005). Balıkçılık Biyolojisi ve Populasyon Dinamiği. Nobel Kitapevi, ISBN: 975-8561-44-8.

Bakes, M., Nichols, P. (1995). Lipid, fatty acid and squalene composition of liver oil from six species of deepsea sharks collected in southern Australian waters. Comparative Biochemistry and Physiology. Part B: Biochemistry and Molecular Biology, 110(1), 267-275. https://doi.org/10.1016/0305-0491(94)00083-7

Bigger, J. (2001). Polyunsaturated fatty acids and cardiovascular events: a fish tale. Circulation, 103, 623-625. https://doi.org/10.1161/01.CIR.103.5.623

PMid:11156869

Bligh, E.G., Dyer, W.J. (1959). A rapid method of total lipid extraction and purification. Canadian Journal of Biochemistry and Physiology, 37, 911-917. https://doi.org/10.1139/y59-099

Bordier, C.G., Sellier, N., Foucault, A.P., Le Goffic, F. (1996). Purification and characterization of deep-sea shark Centrophorus squamosus liver oil 1-O-alkylglycerol ether lipids. Lipids, 31, 521-528.
https://doi.org/10.1007/BF02522646 PMid:8727645

Branstetter, S. (1984). Carcharhinidae. p. 102-114. In P.J.P. Whitehead, M.-L. Bauchot, J.-C. Hureau, J. Nielsen, and E. Tortonese (eds.) Fishes of the north-eastern Atlantic and the Mediterranean, volume 1. UNESCO, Paris.

Cabbar, K., Yığın, C.Ç. (2015). Mahmuzlu camgöz (Squalus acanthias Linnaeus, 1758) köpek balığ 1 karaciğerinin yă̆ asidi profili. Dünya Grda Dergisi, 8, 85-91.

Capapé, C., Reynaud, C. (2011). Maturity, reproductive cycle and fecundity of the spiny dogfish Squalus acanthias (Chondrichthyes: Squalidae) off the Languedocian coast (southern France, northern Mediterranean). Journal of the Marine Biological Association of the United Kingdom, 91(8), 1627-1635. https://doi.org/10.1017/S0025315411000270

Compagno, L.J.V., Ebert, D.A., Smale, M.J. (1989). Guide to the Sharks and Rays of Southern Africa. New Holland, London.

Deprez, P., Volkman, J., Davenport, S. (1990). Squalene content and neutral lipid composition of livers from deep-sea sharks caught in Tasmanian waters. Australian Journal of Marine and Freshwater Research, 41, 375-387.

https://doi.org/10.1071/MF9900375

Fischer, W. (ed) (1973). FAO species identification sheets for fishery purposes Mediterranean and Black Sea (Fishing Area 37). FAO, Rome. 1530 p.

Golani, D., Öztürk, B., Başusta, N. (2006). The Fishes of Eastern Mediterranean. Istanbul, Turkish Marine Research Foundation.

Haag, M. (2003). Essential fatty acids the brain. The Canadian Journal of Psychiatry, 48(3), 195-203. https://doi.org/10.1177/070674370304800308

PMid:12728744

Hall, A. (1992). Signal Transduction Through Small GTPases-A Tale of Two GAPs. Cell, 69(3), 475-479. https://doi.org/10.1016/0092-8674(92)90441-E 
Hoffman, D.R., Uauy, R. (1992). Essentiality of dietary ๑-3 fatty acids for premature infants: plasma and red blood cell fatty acid composition. Lipids, 27, 886-894. https://doi.org/10.1007/BF02535868

PMid:1362792

Ismen, A., Yigın, C.C., Altınagac, U., Ayaz, A. (2009). Length-weight relationships for ten shark species from Saros Bay (North Aegean Sea). Journal of Applied Ichthyology, 25(1), 109-112.

https://doi.org/10.1111/j.1439-0426.2009.01263.x

IUPAC (1979). Standart Methods for Analysis of Oils, Fats and Derivatives, 6th Edition (Fifth Edition Method II.D.19) Pergamon Pres, 96102. Oxford. UK.

Kabasakal, H. (1998). Shark and ray fisheries in Turkey. Shark news 11:14. Newsletter of the IUCN/SSC Shark Specialist Group, UK.

Kousteni, V., Megalogonou, P. (2011). Reproductive biology and embryonic development of Squalus blainvillei in the eastern Mediterranean Sea. Scientia Marina, 75(2), 237-249.

https://doi.org/10.3989/scimar.2011.75n2237

Le Néchet, S., Dubois, N., Gouygou, J.P., Bergé, J.P. (2007). Lipid composition of the liver oil of the ray, Himantura bleekeri. Food Chemistry, 104(2), 559-564. https://doi.org/10.1016/j.foodchem.2006.12.005

Lee, K, Lip, G. (2003). The role of omega-3 fatty acids in the secondary prevention of cardiovascular disease. The Quarterly Journal of Medicine, 96, 465-480. https://doi.org/10.1093/qjmed/hcg092

PMid:12881589

Malins, D., Wekell, J., Houle, R. (1965). Composition of the glyceryl ethers and triglycerides of the fresh and liver of the dogfish (Squalus acanthias). Journal of Lipid Research, 6, 100-105.

Mater, S., Kaya, M., Bilecenoğlu, M. (2005). Türkiye Deniz Balıkları-I, K1kırdakl1 Balıklar (Chondrich-thyes). Ege Üniversitesi Yayınları, Su Ürünleri Fakültesi, Yayın No: 72, Ders Kitab1 Dizin No: 34, Ege Üniversitesi Basım Evi, Bornova-İzmir.
Mytilineou, C., Politou, C.Y., Papaconstantinou, C., Kavadas, S., Díonghia, G., Sion, L. (2005). Deep-water fish fauna in the eastern Ionian Sea. Belgian Journal of Zoology, 135(1), 229-233.

Navarro-García, G., Pacheco-Aguilar, R., Vallejo-Cordova, B., Ramírez-Suarez, J.C., Bolaños, A. (2000). Lipid composition of the liver oil of shark species from the Caribbean and Gulf of California waters. Journal Food Composition and Analysis, 13, 791-798. https://doi.org/10.1006/jfca.2000.0928

Navarro-García, G., Bringas-Alvarado, L., Pacheco-Aguilar, R., Ortega-García, J. (2004a). Oxidative resistance, carotenes, tocopherols and lipid profile of liver oil of the ray Rhinoptera steinchneri. Journal Food Composition and Analysis, 17, 699-706.

https://doi.org/10.1016/j.jfca.2004.01.004

Navarro-García, G., Pacheco-Aguilar, R., Bringas-Alvarado, L., Ortega-García, J. (2004b). Characterization of the lipid composition and natural antioxidants in the liver oil of Dasyatis brevis and Gymnura marmorata rays. Food Chemistry, 87, 89-96.

https://doi.org/10.1016/j.foodchem.2003.10.023

Navarro-García, G., Suarez, J.C.R., Garcia, J.U. (2009). Lipid composition, natural antioxidants and physicochemical characteristics in liver oil from rajiforms from the Gulf of Mexico. Journal of the American Oil Chemists' Society, 86, 323-328. https://doi.org/10.1007/s11746-009-1350-2

Navarro-García, G., González-Félix, M.L., Márquez-Farías, F., Bringas-Alvarado, L., Pérez-Velazquez, M., Montoya-Laos, J.M., Moreno-Silva, B. (2014). Lipid content and fatty acid composition of the liver from the rajiforms Urotrygon chilensis, Urobatis halleri, Rhinobatos glaucostigma, Rhinoptera steindachneri and Dasyatis dipeteura captured in Sinaloa, México. International Food Research Journal, 21(1), 229-235.

Nichols, P.D., Bakes, M.J., Elliott, N.G. (1998). Oils rich in docosahexaenoic acid in livers of sharks from temperate Australian waters. Marine and Freshwater Research, 49, 763-767.

https://doi.org/10.1071/MF97241 
Nuñez, G.C. (2007). Quality And Stability Of Cuban Shark Liver Oil: Comparison With Icelandic Cod Liver Oil, UNU Fishers Trainind Program, Project 2007.

Osman, H., Suriah, A.R., Law, E.C. (2001). Fatty acid composition and cholesterol content of selected marine fish in Malaysian waters. Food Chemistry, 73(1), 55-60. https://doi.org/10.1016/S0308-8146(00)00277-6

Ould El Kebir, M.V., Barnathan, G., Siau, I., Miralles, J., Gaydou, E.M. (2003). Fatty acid distribution in muscle, liver, and gonad of rays (Dasyatis marmorata, Rhinobatos cemiculus, and Rhinoptera marginata) from the East Tropical Atlantic Ocean. Journal of Agriculture and Food Chemistry, 51, 1942-1947.

https://doi.org/10.1021/jf0204809

PMid:12643655

Ould El Kebir, M.V., Barnathan, G., Gaydou, E.M., Siau, I., Miralles, J. (2007). Fatty acids in liver, muscle and gonad of three tropical rays including nonmethyleneinterrupted dienoic fatty acids. Lipids, 42, 525-535. https://doi.org/10.1007/s11745-007-3040-x

PMid: 17404769

Özy1lmaz, A. (2016). Tocopherol, heavy metals $(\mathrm{Cd}, \mathrm{Pb}$, $\mathrm{Cu}, \mathrm{Fe}, \mathrm{Mn}, \mathrm{Zn}$ ), and fatty acid contents of thornback ray (Raja clavata Linnaeus, 1758) liver oil in relation to gender and origin in the Mediterranean and Black Seas. Journal of Applied Ichthyology, 32, 564-568. https://doi.org/10.1111/jai.13041

Özyılmaz, A., Öksüz, A. (2015). Determination of the biochemical properties of liver oil from selected cartilaginous fish living in the northeastern Mediterranean. Journal of Animal and Plant Sciences, 25, 160-167.

Pal, D., Banerjee, D., Patra, T.K., Patra, A., Ghosh, A. (1998). Liver lipids and fatty acids of the sting ray Dasyatis bleekeri (Blyth). Journal of the American Oil Chemists' Society, 75, 1373-1378. https://doi.org/10.1007/s11746-998-0185-6

Remme, J.F., Larsen, W.E., Stoknes, I.S. (2005). Bioactive lipids in deep-sea sharks. Report A0510 Project: Search for Bioactive Lipids in Internal Organs from Deep-Sea Sharks, More Research, Ålesund, Norway.
Sellami, M., Rebah, B.F., Gargouri, Y., Miled, N. (2014). Lipid composition and antioxidant activity of liver oils from ray species living in Tunisian coasts. Arabian Journal of Chemistry, 7(10), 1-7.

Solomon, N., Passwater, R., Joelsson, I., Haimes, L., Buono, A. (1997). Shark liver oil: Nature's amazing healer. New York: Kensington Books, 1997. - XIV, 175 p. ISBN: 1-57566-202-7.

Stehmann, M. (1990). Rhinobatidae. In: Checklist of the fishes of the eastern tropical atlantic, vol. 1. J.C. Quero, J. C. Hureau, C. Karrer, A. Post, L. Saldanha (Eds), UNESCO, Paris, pp. 23-27.

Tortonese, E. (1975). Osteichthyes, (Pesci ossei). Parte Seconda. Edizioni Calderini, Bologna. Fauna Italia, 11, 1636.

Tufan, B., Koral, S., Köse, S. (2013). The variations in proximate chemical composition and fatty acid profile in different parts of the thornback ray (Raja clavata) caught from Black Sea. Journal of Aquatic Food Product Technology, 22, 83-95. https://doi.org/10.1080/10498850.2011.625593

TUIK (2018). Fisheries Statistics 2018. https://biruni.tuik.gov.tr/medas $/$ $\mathrm{kn}=97 \&$ locale=tr $\quad$ (accessed 10.05.2019)

Turan, H., Sönmez, G., Kaya, Y. (2007). Fatty acid profile and proximate composition of the thornback ray (Raja clavata, L. 1758) from the Sinop coast in the Black Sea. Journal of FisheriesSciences.com, 1(2), 97-103. https://doi.org/10.3153/jfscom.2007012

Y1gin, C.C., Ismen, A. (2009). Length-weight relation-ships for seven rays from Saros Bay (North Aegean Sea). Journal of Applied Ichthyology, 25(1), 106-108. https://doi.org/10.1111/j.1439-0426.2008.01161.x 